\title{
WŁADYSŁAW REYMONT’S FASCINATION WITH OCCULTISM: BIOGRAPHICAL AND ARTISTIC THREADS ${ }^{1}$

\begin{abstract}
Władysław Reymont (1867-1925) won the Nobel Prize in literature in 1924; praised for his unique insight into peasants' life, realism and positivistic vibe, he is rarely considered an author interested in esoteric currents. A period of his travel as a medium, his attendance at the congress of The Theosophical Society in England, were marginalized and shown as unimportant events during his troubled life. The analysis of the author's own statements, and tracing esoteric-related motifs in his works, show that the Reymont's own views of his works, and esotericism itself, were quite different. It is not the first time that the biography and intentions of the author tell a different story than contemporary textbooks. The paper traces Reymont's fascinations in Eastern thought, Theosophical current, and Spiritualistic experiments, which were reflected in his works.

Keywords: Władysław Reymont, Western Esotericism and Literature, Theosophy, Spiritualism, Spiritism, Western Esotericism in Poland, The Theosophical Society, Vampire, Józef Drzewiecki
\end{abstract}

Writers and authors who take inspiration from Western Esotericism (cf. Faivre 1994, Hanegraaff 2012) and Occultism (cf. Hanegraaff 2006: 884-889), and reflect those inspirations in their art, are often associated with specific literary niches, like weird fiction or occult romance, and small, obscure publishing houses. This is especially true of the early $20^{\text {th }}$ century Poland. However, interest in such topics was in fact widespread and quite common among the most prominent women and men of letters, too.

This paper focuses on one such figure, a writer who does not really need an introduction either in Poland or abroad - the Nobel Prize laureate Stanisław Władysław Reymont, born Stanisław Władysław Rejment in 1867. A 1913 issue of the Świat magazine said this about his works:

Who among contemporary people does not know »The Peasants«! (Reymont 1904-1909) Who has not commiserated the fate of »The Comedienne«? (Reymont 1896) Who has not listened to the intense pulse of labor and trade speculation in the stale and smoky Łódź, which is so transparent and bright in

1 This research was carried out within the framework of the Minister of Science and Higher Education's programme entitled "National Programme for the Development of Humanities" in the years 2016-2019: Polish Culture in Relations to the Western Esoteric Philosophy in the Years 1890-1939 (0186/NPRH4/H2b/83/2016). 
Reymont's vision? (Reymont 1899) The element is rolling and raging in all works by the author of the "Impressions from Chełm « (Reymont 1911b). Like "The Vampire« (Reymont 1911b), it lurches over arable land or covers bricks and concrete with a great city fog.

Connecting Reymont with Western Esotericism may be surprising to many, considering that none of his best known novels alludes, at least not in any direct way, to topics or ideas of this kind. His best known work, The Peasants, is a novel in four volumes (Spring, Summer, Autumn and Winter) describing in great detail the life of the Polish countryside. Accordingly, Reymont is usually perceived as a representative of Positivism (apart from the name of a philosophical current and scientific method, in Polish literary history Positivism is a literary current which succeeds Romanticism, and precedes Young Poland), who captured both the simplicity and the uniqueness of life structured by labor and the closeness of nature, a writer who combined realistic prose with elements of expressionism (Reymont 1986: 2 of the cover).

By the turn of the $20^{\text {th }}$ century, literature referring to the spiritual realm had already become one of the most popular kinds, as the fascination with spinning round tables, bilocation, clairvoyance etc., held its grip on the popular imagination until the outbreak of the Second World War. From our contemporary point of view on the past, it is not always obvious how popular these topics really were, as works concerning Spiritualism, Theosophy, Magic, read widely at the time, were later neglected and marked as a passing quirk that went away along with the decadence of the end of the century. Such interests were often marginalized and forgotten, sometimes actively removed from biographies of noble authors, to the point where they were almost bleached out. While Reymont's early fascination with Spiritualism is known to literary scholars, it is never discussed in this context by the wider audience, especially not in schools, where his novels are part of the curriculum. The present paper analyzes the more obscure motifs in Reymont's work, as well as the better known ones, but from a different perspective than usual - with regard to his fascination with the esoteric currents of his times.

\section{Biographical note}

Władysław Reymont was born in 1867 in the village Kobiele Wielkie (in Polish territory under Russian rule at the time) as the fifth of nine children of Józef Rejment and Antonina Rejment (nee Kupczyńska). His father was a trained musician and worked as a church organist; his mother came from impoverished gentry. The Rejment family was relatively well off and the parents strived to provide education for the children, although Reymont himself described his childhood in such a way so as to make it seem that the family could barely sustain themselves (Reymont 1924). 
The family moved from Kobiele Wielkie to Tuszyn, to their own farm, one year after Władysław was born. It is worth noting that the writer was born not long after the January Uprising against the Russian occupation, which took place in the Polish lands in 1863-1864. The uprising was unsuccessful, but the whole family, especially on Władysław's mother's side was engaged in it. Antonina, already a mother of four, was a courier in the uprising, and biographers emphasize that the uprising cast a permanent shadow on Reymont's family (cf. Kocówna 1986: 10-11, 1971: 6-19).

Against the will of his parents, who wanted him to follow in his father's footsteps, Władysław refused learning to play the organ; he was also unwilling to go to school, so instead he travelled a lot. As a young man he often changed professions and residences; he finally trained to be a cobbler, and graduated from a Sunday Craftsmen School. He worked temporarily in a theatre and in railroads; he tried acting and writing. He wrote novels, short stories and reportages. His long-lasting financial problems were resolved after a serious rail accident in 1900, from which he received a huge compensation for sustained injuries from the Tsar's Railroads (the health problems caused by the accident, however, remained with him until the end of his life).

The accident happened when Reymont was travelling in the company of an editor of "Gazeta Polska", Jan Gadomski, and his sister. Not far outside Warsaw the train collided with another one; many passengers were killed, including Gadomski's sister. Later Reymont would say that he was miraculously saved, but the accident haunted him to the end of his days. He'd had many health problems even before the accident, among others with his lungs, heart, and liver; and probably as a result of these he suffered from depression. While going through jaundice (before the railway accident) he wrote: "I will never be dispirited by lack of money, but only by disease, and especially one like this that's holding me now. It's boring, disgusting and painful. But I console myself that it has to pass" (Kocówna 1971: 132). The accident exacerbated Reymont's problems, and he was unable to write for a time.

Reymont married Aurelia Szabłowska in 1902, after six years of engagement. It look longer than usual due to a prolonged divorce case between Aurelia and her first husband, but also because Władysław and Aurelia broke up and got engaged again at least twice during this time; he probably got engaged to someone else in the meantime (and was possibly going to visit the other fiancé when the accident happened) (cf. Kocówna 1971: 74, 117, 131). 


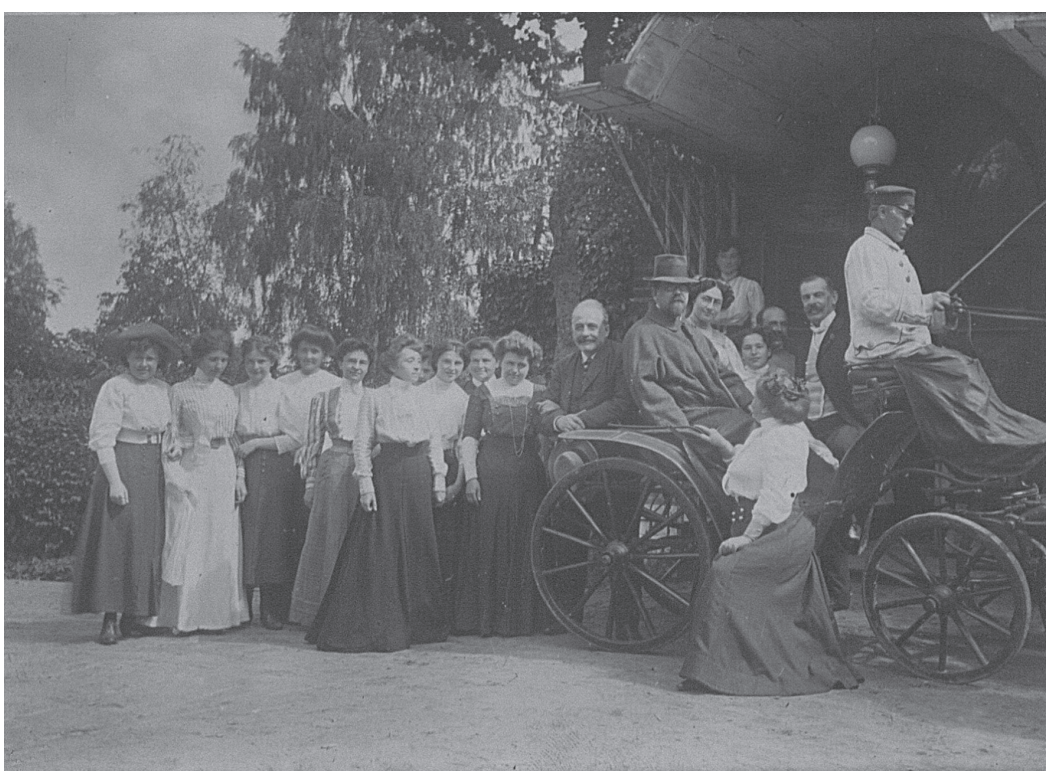

Fig. 1. Władysław and his wife Aurelia Reymont with their friends in Florianów (1909). Courtesy of the National Library in Warsaw.

In his biographical note for the Swedish Academy, Reymont recalled his childhood and said that he had been fascinated with literature from a young age. He also developed a special interest in poetry, especially Polish romanticism. He wrote:

[...] my brother, who had left college, tried systematically to make me pursue a regular program of studies. He took infinite pains, but did not succeed in tearing poetry out of my heart. I was at that time intoxicated by the romantic poetry of our great writers. I arranged the world according to my private use, looking at it through the poems I had devoured.

Within myself I felt vague enchantments, dull restlessness, and uncertain desires. I had hallucinations when I was awake. What wings carried me to unknown worlds! (Reymont 1924)

Reymont's most important works were written from the 1890s on. Like the characters of his novels, he worked in a very systematic manner, devoting five hours to writing each day. He spent his evenings reading ("Świat" 1913). He was awarded the Nobel Prize in literature on November $13^{\text {th }} 1924$, "for his great national epic, Chłopi" (The Nobel Prize.org). The significance of his achievement is underscored by the fact that among the nominees were other laureates-to-be, Thomas Mann and George Bernard Shaw. Reymont died one year later, on December $5^{\text {th }} 1925$ in Warsaw.

Barbara Kocówna, Reymont's biographer, mentions three wellknown portraits of Reymont, which provide an image of him as a person 
and an artist (1986: 5-10). The first, most popular portrait was painted by Jacek Malczewski - a Young Poland artist (Young Poland was the name of a modernist current in art, literature and music in Poland between 1890 and 1918), known as the father of Polish Symbolism. It presents Reymont as a monumental figure - the author of the epic novel The Peasants. The writer's surroundings in the painting allude to this work. When Malczewski painted the portrait, Reymont was already among the most renowned novelists in Poland. The second portrait, by Leon Wyczółkowski, shows Reymont as a cheerful and friendly person. The third one (included here) was painted by Mieczysław Jakimowicz, who was the writer's nephew and friend, and therefore knew him much better than the other artists. Jakimowicz gives Reymont's face, and especially his eyes, an eerie look; the figure is placed against an obscure, ghostly background. We can imagine that this is how the writer sometimes seemed to those close to him (Kocówna 1986: 5-6). It is on this more mysterious side of Reymont, his interest in Mysticism and Esotericism, and its reflection in his work, that we will focus on.

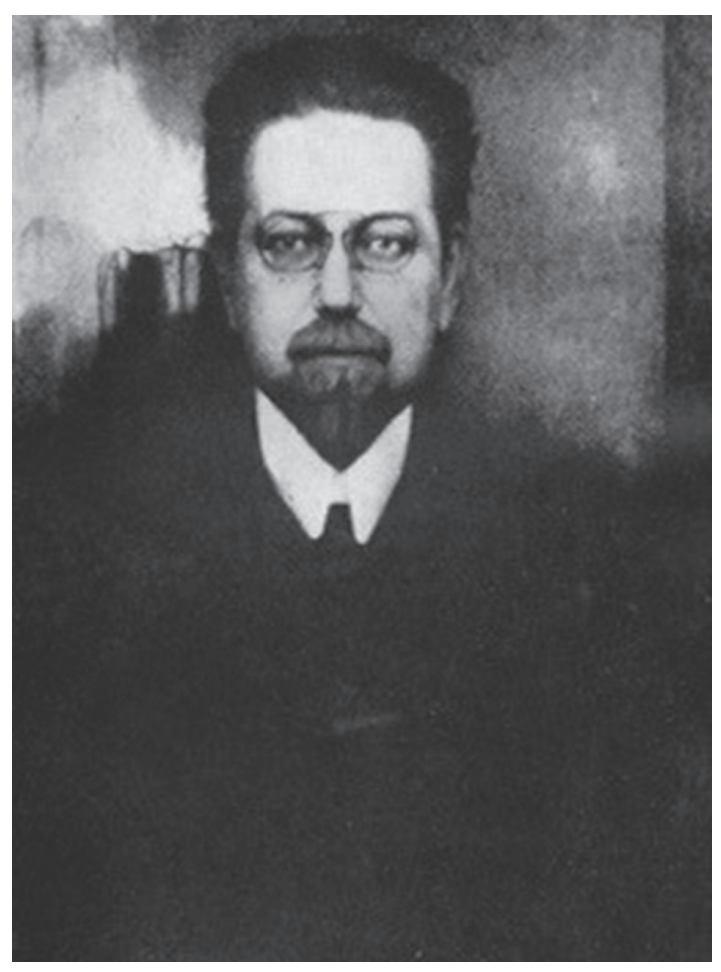

Fig. 2. A portrait of Władysław

Reymont by Mieczysław Jakimowicz (1909).

We should note here that Władysław might have also had an influence on young Mieczysław's art. The latter became a part of the artistic "Group of Five", a circle of painters whose works revealed their interests in symbolism (see Geron 2006: 13-14).

\section{The chosen one of Spiritualists}

A closer look on Reymont's work reveals a great fascination with the Romantic legacy of idealized representations of nature, as well as with the knowledge of the East, which the author acquired through Theosophical writings, and with spiritualist practice. His adventures with Western Esotericism began in early youth and they are among the most underrated inspirations for Reymont's artistic work. 
Although one can find a lot of scattered information from many short biographical notes, which include some mentions of his esoteric-related interests, many of the sources actually get them wholly or partly wrong, thus leading to misconceptions. We can find, for example, information about Reymont meeting a German professor named Puszow (the name suggesting Eastern European or Russian origins) in the late 1880s or early 1890s, a man who was a practicing Spiritualist (Bukowski 1927: 7). Separately we find out that Reymont had a teacher in secondary school with whom he was discussing issues related to esotericism from his early years (several of Reymont's later remarks indicate that he knew the teacher from his gymnasium years, but he never mentions that he discussed any such topics with him back in school; he seemed rather surprised by the discovery of Mr. P.'s practices). The most reliable source, however, based on multiple archival data, states that Reymont did in fact have a German teacher in secondary school, but his name was most probably Pusch (a name popular in the area at the time and connected to the school in other sources), and about whose Spiritual interest he found out only as an adult person, in February 1890 to be precise (Kocówna 1971: 35). Reymont himself did not make it any easier to find out the teacher's name, often referring to him as Mr. P: in a letter to his brother he used name Pusch, and in a later autobiography for A. Wodziński he wrote Puschow, but the former version is correct according to W. Tokarz (cf. Reymont 1969: 170-171, Krzyżanowski 1937: 2-8, Sołtysik 2005, and Tokarz 1925).

Mr. P.'s interest in esotericism surprised Reymont, as he wrote, especially the fact that he learned about them by literally walking into a spiritualist séance when he once dropped by to visit his old teacher. He was redirected to the house of family Rosicki, where he was greeted by Mr. P. and other persons (unknown to him at this time), who came to him and bowed their heads saying "Praise be!". Reymont was told by Mr. P. that they had all gathered with the purpose of meeting him. During previous séances they were given directions that on the day of February $10^{\text {th }}, 1890$, at 7 o'clock PM at that exact place in Częstochowa the chosen person would come. They also had details of his appearance. He was said to be chosen "to pronounce the spirit and overcome matter with the spirit", and therefore he should leave everything and devote himself to the study of Spiritualism. Reymont opposed this, based on his lack of money and strong materialist beliefs, but he was soon convinced by them, through mysterious phenomena of the "purest spirituality of men" (Reymont 1969: 170). Later they also provided him with money for upkeep and education. Reymont wrote to his brother "Franek, I am not under the influence of hallucinations, I am entirely sane, and fully aware of everything - and yet when I think about what happened to me, about the direction that my life will take, I am afraid of myself, I am afraid of going mad" (Reymont 1969: 170). The writer also mentions that he later learned that the participants of this event were world-famous Spiritualists, among 
others “dr. Cyriax from Berlin University, dr. Roberts from Nancy, dr. Lombroso from Bologna, dr. Philips from Paris", and many others whom he did not remember (Reymont 1969: 170).

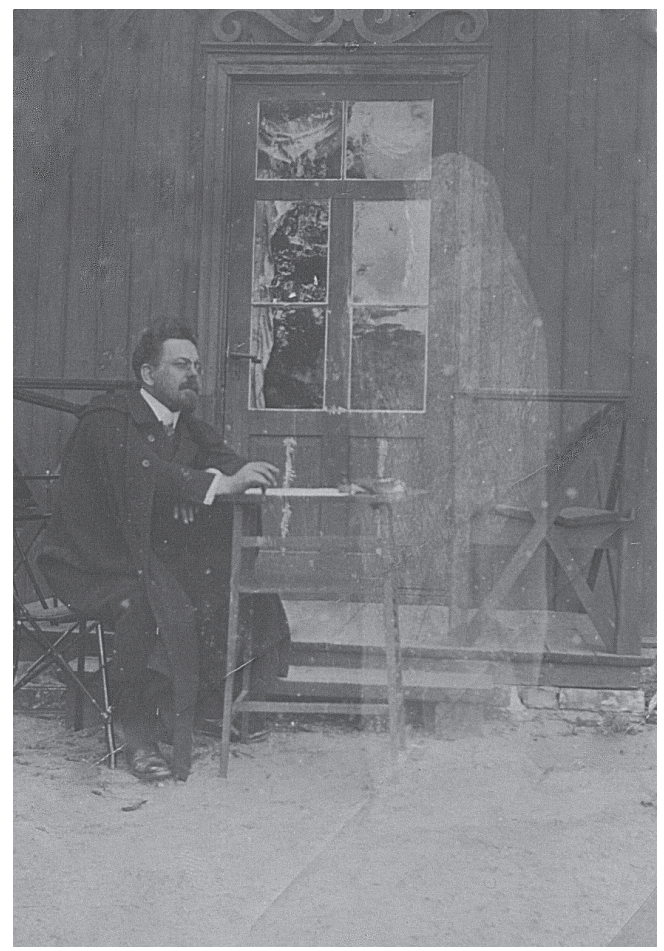

Fig. 3. A peculiar photo of Władysław Reymont exposing his interests. Reymont and the ghost, photo probably by Władysław Zahorski (1905). Courtesy of National Library in Warsaw.

As Reymont told the story, he eventually accepted the proposition of the Spiritualist circle and agreed to travel with them and to study the mysteries of the Spirit (Reymont 1969: 170). From another account, we can learn that he did in fact travel with $\mathrm{Mr}$ P. and his medium, although no other participants of the meeting are mentioned. During this period he visited, among other places, Vienna and Wrocław, where the Church of Spiritualists was located (Bukowski 1927: 7). Given Reymont' financial troubles at the time and his interest in all things mysterious, the explanation of his decision to join the Spiritualist circle he gave to his brother is convincing enough. On the other hand, the details of the event he describes are implausible (who knows, maybe a group of renowned Spiritualists did indeed come to the city of Częstochowa to meet Reymont and teach him about their doctrines?). One may speculate that Reymont made up the shocking story to disguise his pre-existing interest in Spiritualism and his travel plans. Including a number of famous names in the story may have served to legitimize his choice - which could otherwise seem quite irrational - to drop everything and join a circle of Occultists on a religious quest.

Given the travel to the "Church" in Wrocław, we may assume that Reymont made contact with the Spiritists. But his statements also indicate that the group connected to Pusch had strong Theosophical ties (which is not mentioned in his biographies). He described Mr P. as being familiar with Theosophy, and really engaged in the ideas of that current. Reymont wrote about it in his short auto-biography prepared for the Nobel Prize ceremony: 
A world of fantastic dreams and possibilities opened before my eyes. I left my job and went to join the professor, who lived in Czestochowa. He had constant and close contact with spiritualist circles in Germany and England, corresponded regularly with Madame Blavatsky and Olcott, wrote in spiritualist journals, and was always giving ad hoc séances. For him, spiritualism was both a science and a religion - a mystical atmosphere prevailed in his entire house (Reymont 1924).

As we know from other sources, Reymont possibly also acted as the professor's medium (cf. Markiewicz), but he never mentioned this in his own statements. However, the adventure with Spiritualism did not last long. Reymont later stated that he was able to notice very soon that the professor, who was kind but also childishly naive, was being deceived by his medium. After a series of séances Reymont's "faith in miracles was lost", and he left the group immediately. After that, he said, "once more I was free, penniless, and without a tomorrow" (Reymont 1924). Regardless of how much of Reymont's account of his introduction to the Spiritualist practice is true, it is notable that the story of being the Chosen One is so rarely mentioned in the context of his artistic creativity and spiritual background.

But one should not be misled to think that Reymont's interest in Western Esotericism ended then. Besides his account of the consequences of meeting Mr. P. in Częstochowa, other documents (see manuscripts of W. Reymont in the Archives of Zakład Narodowy im. Ossolinskich in Wrocław, signature 6971/1: 39-42) clearly indicate that he was involved not with a loose group of spiritualists, but that in fact he was a member, and perhaps one of the founders of an official spiritualist organization - the Warsaw Psychological Society [Warszawskie Towarzystwo Psychologiczne]. The society was established but not certified by the authorities (Hass 1994: 82-83). While the founders used the term 'psychological', referring to all psyche-related phenomena, their interests were closer to psychic than psychological issues as we understand them today. We have to remember, however, that at the time psychology was only coming into existence as a field, and it sometimes included research on Mediumistic phenomena as well; therefore it was not that strange after all to call the society of this sort "psychological". In Reymont's archive we can find a statute of the group from October $15^{\text {th }} 1890$. Since besides other names ${ }^{2}$ we find "Reimont" in the society's founding documents, it is most probable that the later Nobel Prize Laureate was one of the eight cofounders of the society (his name was often misspelled, cf. Kocówna 1971: 37). What is more, it was Reymont again who became a board member of one of the Polish parapsychological journals - Zagadnienia Metapsychiczne [Meta-psychic Issues], published between 1924 and 1929, which is not mentioned in his biographies. Reymont was in its board already

2 E.g. Ignacy Matuszewski, a literary critic and writer who wrote a book on medium-related phenomena called Sorcery and Mediumism (Matuszewski 1896). 
from the 2nd issue (April-June) in 1924, and continued his work until his death, as the last issue he edited was from December 1925, the same month he passed away (see Zagadnienia Metapsychiczne No. 2-7, Vol.1-2, 1924-1925).

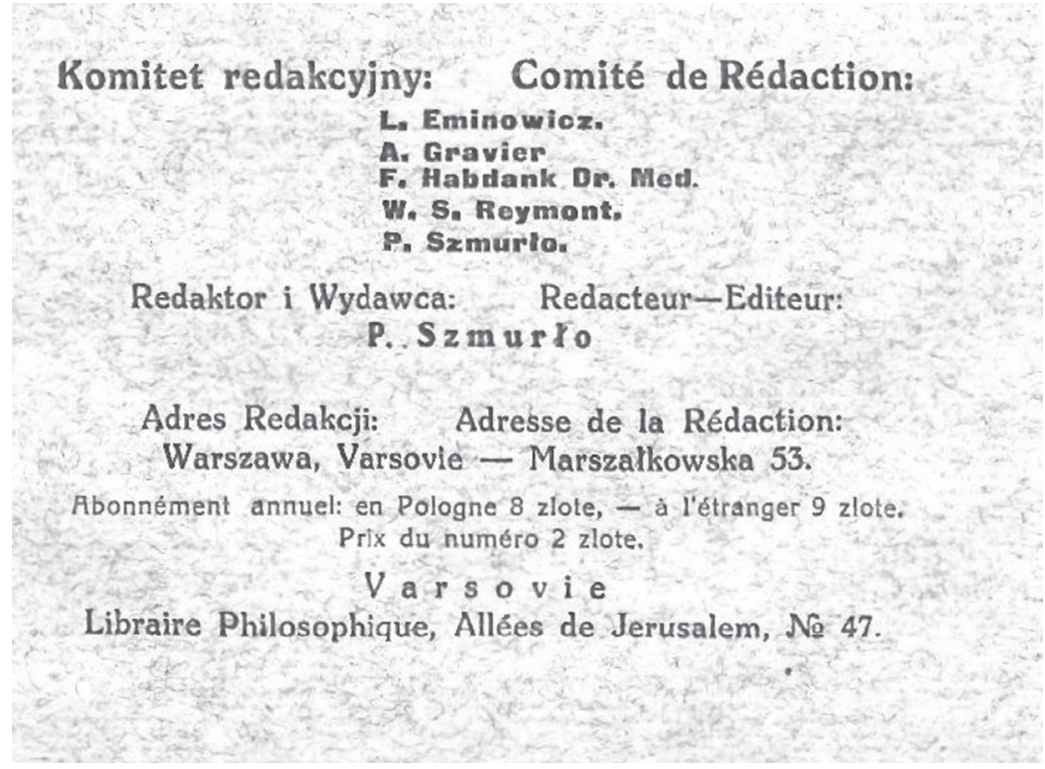

Page two of the cover of an issue of Zagadnienia metapsychiczne with a list of the editorial board members.

\section{Theosophical Peregrinations}

My last research visit to The Theosophical Society in England ${ }^{3}$ led me, through various leads, to discover that Reymont was in touch with Occult and Theosophical circles again very soon after the previously described events, or even never suspended such contacts in the first place. From one source we learn that a man called Władysław Walderowicz helped Reymont with his first publication (cf. Markiewicz). In other sources we find that Walderowicz was an Occultist (Hass 1994: 80). What was unknown until now - as I found the Membership Register of The Theosophical Society in England from the 1890s - that Władysław Walderowicz was a Theosophist. His sponsor (the introducing member) was Dr. Józef Drzewiecki (Theosophical Society in England, Membership Register Index, 1893) - a renowned physician and homeopath, whom Reymont later accompanied to a Theosophical congress.

The first publication of Reymont's' works happened in 1892, and therefore we should assume he was in contact with Walderowicz around

3 I would like to thank Leslie Price for his help with the various sources in London. 
that time. The Theosophical congress which he attended took place two years later. Those two facts indicate Reymont's constant engagement with esoteric milieus, even after the supposed breakup with Mr. P's Spiritualists. Some biographers state that Reymont went to London with different purpose, and took part in the Theosophical congress only by accident or incidentally. However, he himself wrote "I went to London to pursue spiritualist problems at the Theosophical Society," (Reymont 1924), so there is no doubt that the meeting to which he was invited by Drzewiecki was the main reason to add London to his summer travels. The journey made a great impression on him. He described his experiences in a biographical essay Summer 1894 Abroad (1948).

Reymont is not very explicit about the circumstances of the congress he attended, but we know that he was referring to a meeting that included international delegates which took place at the Blavatsky Lodge, on July 13-15, 1894 (this has been confirmed in the Theosophical Society in England). The congress included a number of eminent participants: the first president of the Theosophical Society, Henry Steel Olcott (1832-1907); his later successor Annie Besant (1847-1933); Madame Blavatsky's personal Secretary, George Robert Stowe Mead (1863-1933); and William Quan Judge (1851-1896), the General Secretary of the American Section of the Theosophical Society (which at the time still belonged to the Theosophical Society Adyar structures). About Mead, Reymont wrote that he was a "very nice thirty-something man with a cold and penetrating gaze" (Reymont 1948: 15). The author was intrigued by the meeting, and in his memoir elaborated on some details - from the portrait of Blavatsky in the room, through decorations, to the speeches and appearances of delegates from different countries (Reymont 1948: 14-18). But he mainly focused on Annie Besant:

The night was falling down slowly; lamps were lit and the session resumed. When Olcott stood up and started talking about Mahatma, who'd brought him various trinkets from the other world, a new personality entered the room: a slim woman, dressed all in white and resembling Isis. They all rose, until she walked across the room, tilting her head to the left, and sat down in the honorary seat. All eyes were fixed on her. It was the famous Anna Besant, a comrade of Blavatsky, and as it were her successor, the author of "Theosophy" [he might be referring to one of Besant's pamphlets, e.g. An Exposition of Theosophy from 1893, note by $\mathrm{KMH}$ ], a work immensely popular in some circles. The speeches continued, but most people were not listening, only looking at Mrs. Besant. Finally, she spoke herself, talking about the Mahatmas. She spoke very quietly, but her incredibly resonant voice carried across the whole room (Reymont 1948: 17).

After Dr. Drzewiecki's speech, which Reymont was not authorized to write about, the gentlemen were approached by Besant, and Drzewiecki introduced Reymont to her. Since he had an opportunity to meet her in person, he gave more details of the impression she made on him: 
A very strange woman. Her face is such that she can look twenty-five years old one minute, and then from a closer look she looks fifty. She has a huge head of hair, completely grey. Her face is not pale but completely white, without a drop of blood or a single vein. A low and ugly forehead, deeply wrinkled over the eyebrows. Thin lips, big rather deep-set eyes, and an immense sweetness and kindness expressed on her face. She doesn't look at anyone when she speaks, and she tilts her head forward, which makes her look somewhat shy. And this white outfit of a Roman woman [sic!] adds to the mystery of her person. She has a strange gaze, like the gaze of $\mathrm{Nari}^{4}$ the Mother from the original Indian trinity, a statue of whom I saw in the British Museum, i.e. it is frightened and deceitful at the same time. The whole mask of her face is so still that one cannot really discern her expression through the sweetness and kindness that seem to be plastered onto it. She told us about Blavatsky, about India, about the backwardness of the materialistic doctrine dominating Europe and the obstinacy of certified scientists, who reject everything they do not know and do not understand. She spoke almost in aphorisms, and summarized splendidly the conceit of pseudo-knowledge and pseudo-scholars. They are fools, who have seen and groped the clothes of man and they don't look any deeper, because in their conceitedness and laziness they took the clothes for the body itself, for the core of everything, while the core is a thing more valuable than anything else - the soul, as it was described in the Elefanta [?]: I am everything and in everything.

Wolbórka, 27 August, 1894 (Reymont 1948: 17-18).

As far as we know Reymont himself never joined the Theosophical Society, but it appears it became his lifelong interest, as in an interview about his readings he gave in 1913 (i.e. two decades later), which was published in the magazine "Świat" [World], Reymont confessed: "I passionately love travels. Among Polish authors, I always like to return to Rzewuski and Krasicki. Of the contemporaries, I always read Żeromski and Tetmajer with great interest. In any case, I read a lot. I like Theosophical works, especially the Hindu ones" (Reymont 1924). Reymont obviously did not hide his interests, but they were largely unnoticed or dismissed as unimportant by his commentators and biographers, which is a common situation with Esoteric currents (cf. Hanegraaff's notion of rejected knowledge, 2012).

\section{Other Esoteric and Occult-related inspirations}

A piece of Reymont's self-description very important from the perspective of the study of Western Esotericism can be found in his notes, where, starting from 1894, he describes himself as an Occultist - not a

4 Reymont's text contains many errors, possibly resulting from the fact he never prepared it for publication (it was only published many years after his death); typographical errors may result from misreading of the manuscript. Here Reymont probably meant Shakti. 
Spiritualist or a Spiritist (hence it is Occultism which is included in the title of this paper). One thing that influenced him in this respect was most likely Theosophy. During the Theosophical congress he must have heard a lot about differences between the Occult philosophy and Spiritualism, and possibly some criticism directed at the latter. Another factor was surely his acquaintance with Julian Ochorowicz (1850-1917), reflected in the fact that Reymont used the notion of "Mediumism". Ochorowicz was a Polish scientist, psychologist and inventor who became involved in research on the phenomena of Spiritualist séances. He searched for naturalistic explanations of the observed events, and developed theories based on contemporary physics. Not to be mistaken with Spiritualists who were looking for otherworldly causes, he called himself a researcher on "Mediumic phenomena" (cf. Hess, 2018: 239-274). Reymont wrote in his notes: "The Mediumists and Occultists, people who for the most part think more deeply, and beside knowledge also possess a love for truth, keep their distance from Spiritists"; he also began to more or less openly criticize some members of the abovementioned Warsaw Psychological Society, e.g. calling W. Chłopicki "the legs of local Spiritualism, because he certainly cannot be the head" (Kocówna 1971: 38).

Reymont met the "famous Dr. Ochorowicz" soon after coming back from his trip to London, in the mid-1890s. (Reymont 1924). Not many people know, however, that The Peasants, the novel for which he was awarded the Nobel Prize, was inspired by his observations of rural life in the village of Wisła, where Reymont was visiting Ochorowicz. The latter designed and financed the building of residential villas to which he invited his friends and acquaintances, mostly from the Polish cultural elites, turning the place into a small touristic center. Reymont spent a lot of time in the natural surroundings of Wisła, and worked out his ideas there, but he also participated in Ochorowicz's experiments in Mediumic phenomena and hypnosis. This had a big impact on him. Ochorowicz was skeptical about the metaphysical conceptions of Spiritualists and all others who assumed interventions of spirits; instead he tried to explain mediumic phenomena through the prism of his theories of the philosophy of physics, and to account for their mechanics through concepts such as the transformation of forces, the energy of the medium and the participants of the séances, changes in the density of aether, etc. He believed that mediumic phenomena are a kind of hypnotic phenomena. His best known works in this field are On Mental Suggestion (first published in French as De la suggestion mentale, 1887) and Mediumic Phenomena (in Polish, Zjawiska mediumiczne, 1913).

Reymont, familiar with Ochorowicz's theories of mental suggestion, hypnotism and magnetism, often referred to them in his works. Descriptions of hypnotism appear in several different contexts. Many disorders were supposedly caused by hypnosis, and they could be cured by it as well. In the novel The Vampire we can find a description of the protagonist, Zenon, being induced into a hypnotic state by a Theosophist, dr. Smith: 
[Zenon] tried to connect with the torn memory which wandered around his brain, but he suddenly found himself in darkness, faint flashes escaped his consciousness like a lifeline from the hands of a drowning man, he looked at Joe and shivered... he tried rising from the sheets... he wanted to scream... he wanted to say something, but he remained stiff, with his arm stretched out... struck to the core with his steel, hypnotizing sight, he suddenly relaxed and fell to sleep.

- You will sleep until morning, and you will sleep calmly. You will wake healthy and with no memory of anything, anything at all! - he suggested to him with all force, making long, soporific gestures over him.

- You hear only me and it is only me that you understand, and only me that you answer! - Joe whispered to him, pressing fingers on his temples and eyes (Reymont 1986: 168-171). ${ }^{5}$

Ochorowicz also studied the phenomenon of split personalities in mediums during hypnotic séances, as well as - and this is of particular interest in the context of Reymont's writing - the mechanism of aetheric twin creation. They were supposed to be responsible for the phantom images appearing during séances, which is also described in the novel.

For Reymont, Nature had a spiritual character. He said: "Nature has one of the most devout worshippers in me. That is why I keep reading the works of (Joseph) Rudyard Kipling (1865-1936) ${ }^{6}$, for he, for his relation to nature and to animals, is the only writer today who understands and feels those worlds which are inaccessible for many people." ("Świat" 1913). In many of his own works, Reymont reflects on the possibility of becoming united, even in a mystical way, with nature. This may be surprising for some, as he is usually seen as a realist writing about nature from a very different perspective. The motif of unification in the context of augmentation of consciousness through the use of psychoactive substances is also present in Reymont's writing, for example in the novella In an Opium Den:

I felt that I was only consciousness. I recognized that I do not see, do not feel, do not hear, only know. A whitish little cloud of mist was me. Whenever I remembered something, it was as if blue and purple flames, like lightning, flew out of my "I". I felt in me the serenity of immense happiness. I was running through some magical worlds. I was flowing in a green ray of light. I was in the universe. Billions of suns swayed around me as if white, yellow and purple flowers. Unnumbered whirlwinds of rays crossed spaces [...] I was everywhere, but I could not want, I was as if dissolved, transparent, present everywhere (Reymont 1932: 102).

5 Mental suggestion, autosuggestion and mediumism are mentioned also in diferrent parts, see p. 203, 281, 282, etc.

6 It is worth noting that Kipling (like his father) was a member of Freemasonry. The topic appears also in his poetry, see e.g. Man Who Would Be King. He was initiated at the age of 20 in the Hope and Perseverance Lodge, No. 782, English Constitution in Lahore, Punjab, India, and later some other lodges. Kipling himself mentions activities in his own lodge in India, see Kipling, Rudyard [entry] in Mackey's Encyclopedia of Freemasonry, online version at http://www.phoenixmasonry.org/mackeys_encyclopedia/k.htm [accessed 12.09.16]. 
There is at least one more esoteric-related, but also personal, inspiration for Reymont that should be mentioned while tracing his heterogeneous spirituality. Reymont was friends with Stanisław Przybyszewski (1868-1927), a charismatic Polish writer who began his career in Germany, and who was interested, personally as well as artistically, in Satanism and Witchcraft. There are a few letters exchanged between the two gentlemen, and mentions of each other in both their biographies. They were close enough for Reymont to ask Stanisław to send his letters from a different country when he was hiding the information about his new fiancé and their journey together from his family and friends (cf. Przybyszewski 1954, Reymont 1975). It is rather obvious that many details of Reymont's The Vampire come from a fascination with Przybyszewski's works. It was Przybyszewski who wrote that "the axis and foundation of both the Sabbath and the mysteries is an unbridled sexual desire" (Przybyszewski 1999/2000: 110), who dwelled on the dualistic and rebellious heritage of Manicheans, and most of all, who elaborated on the figure of a satanic, demonic woman.

However, this is more than just ornamental, as I believe that we may read Reymont's entire novel as a competition of two worldviews - a Theosophical pantheism and a radical dualism inspired by the decadent Przybyszewski (which was Gnostic in spirit, and demonized Nature); ${ }^{7}$ a static mysterious unity on the one hand, and a worldview connected to Androgynic symbolism of dualistic change and movement, on the other. ${ }^{8}$

Despite these connections and inspirations, the two authors are rarely compared, and if so, they are presented as opposites. This can be clearly seen in one of the essays published in 1925, the year when Reymont won the Nobel Prize; the author, Zdzisław Dębicki, elaborates on many of Reymont's novels, but doesn't mention The Vampire even once. What is more, he writes that "this brain eroticism [sic!] introduced to our literature by Przybyszewski is alien to Reymont." And he elaborates further:

In comparison to all this, to which our literature, and not only ours, has accustomed us, in comparison to all this erotic perversion, which despite even the most artistic clothes it can put on, remains a perversion, in comparison to all this operation of modern art, decaying, exciting and dangerous like a poison, peeping through the curtains on scenes in bedchambers and boudoirs - Reymont's art is in this domain something so honest, open and simple, that one cannot wonder enough at its sunny, Greek-like joyfulness, which has nothing to do with the "moods" of the time and the generation to which this exceptionally talented writer belongs. (Dębicki 1925: 11-12)

We can guess that Dębicki was not thinking, for instance, of the following fragment from the Vampire- a book hard to oversee, as it was pub-

7 Przybyszewski was fascinated by Manicheans, and their ideological descendants: Albingens, Kathars, Adamits etc. (see 1991/2000: 74-111).

8 A problem of Przybyszewski interest in Gnosticism is analyzed in a book by Artur Jocz (2009: 13-66). 
lished (fourteen years earlier) by an author with an already established reputation, who had by then written the great novel for which he was awarded the Nobel Prize:

Suddenly there was a terrifying roar, a golden band of lightning jumped across the cavern, everyone fell down on their faces, bloody flames spurted upwards like a volcano erupting and came quietly down, and then clouds of goldish incense smoke began to gush. From between them, slowly, in the mortal silence of becoming... emerged the figure of Baphomet... [...] he was all naked, slender, youthful... he was sitting with his knees wide apart, and between them a bloody lightning writhed like a venomous snake... the curved claws of his long, hanging arms touched the shroud of specters with stood at his golden hooves... [...] it seemed that he has appeared only for an eye-blink, and in a moment he would throw himself back into the chasm, to run across frigid deserts of silence and to run always, in infinity, in eternity.

A shiver went down his spine, he would give all his life now to be able to see her face... but he only saw, as if through thick fog, her slender naked body, clad in a cloak of hair the color of rust, standing between Baphomet's knees! (Reymont 1986: 159).

Interestingly, Baphomet is always on the move here, that is exactly like Przybyszewski described himself: a meteor (or a comet perhaps) among unmoving stars. The female protagonist of the novel fits the motif common in modernist literature, that of a devilish femme fatale (Janion 2008: 218-220). It is worth noting that she looks similar to the red-haired lady that appears in Edward Munch's painting "Vampire", previously called "Love and Pain" (1893). It is possible that Reymont, who couldn't make a decision about the final title of his most controversial novel, was inspired by Przybyszewski's colleague, as he met both artists at the same meeting in Paris in 1898. It is worth noting that the Baphomet he describes is without a doubt directly inspired by the most recognizable picture by Eliphas Lévi's (Alphonse-Louis Constant, 1810-1875), whose work he would have to had encountered during his esoteric peregrinations in Paris, or through his friends inspired by the esoteric currents of a decadent era.

While Reymont was clearly a believer in the supersensible world, and his beliefs appear to be strongly connected to a heterodoxical spirituality, Theosophy and Spiritualism, these elements are rarely mentioned in discussions of his religiosity. Meanwhile, accounts of his contemporaries reveal an image of a person not just believing in but absolutely convinced of the reality of an afterlife:

The strength of Reymont's faith in an existence beyond the grave was a unique phenomenon in our time. He spoke of it with his usual candor and eagerness, and so straightforwardly that I remember being always struck with wonder. He spoke about death and meeting again in the other world with such a simple inflection, like others speak of travelling to America and meeting in New York. I often listened to it with amazement and deepest respect. Only great souls can afford such a power of faith (Choynowski 1926: 38). 
It is possible that it was indeed faith that made Reymont speak so directly about life after death, but it is highly probable that Reymont was actually convinced that the existence of afterlife had been proven experimentally, and that he himself had participated in such experiments.

In an article concerning Władysław Reymont's religiosity, Jakub Malik discusses at length his complicated relationship with the Catholic Church, but emphasizes his unwavering faith in God. In his analysis, however, Malik does not investigate how Reymont understood his God, and framing his beliefs in the default terms of Christian monotheism leaves no space for considering the deity in ways taught by e.g. Theosophy (cf. Malik 2002: 49-64). Meanwhile, Reymont himself spoke explicitly about the religious aspect of Theosophy, even if he also considered Mr. P.'s engagement in it - to invoke once again the account discussed earlier - as equal parts religious and scientific.

\section{The Vampire}

We have already mentioned The Vampire, an interesting novel and a very important one for Reymont himself, but also one which never became as popular as other Reymont's novels. Different in character than his most recognizable works, it is less known, which is not to say it is the only one of its kind among Reymont's works. Similar motifs can be found in The Dreamer [Marzyciel] from 1908, and in the novella Séance [Seans] (Reymont 1951); in fact, he wrote extensively on liminal topics, to mention only oneiric short stories (see Walczak 2002: 123-142) Cronicles of Dreams [Senne dzieje], Scream [Krzyk], I am waiting [Czekam], Storm [Burza] or A strange story [Dziwna opowieść].

The Vampire was published in 1911, when Reymont was already a mature and established author. The novel is usually considered by critics to be rather bizarre in both its form and subject matter, and less than successful artistically (Krzyżanowski 1937: 19-20). In effect, not much attention was devoted to it, although this has started to change more recently (cf. Trześniowki 2002, Sell 2016, Kruszczyńska 2012, etc.). Nevertheless, from the perspective of the study of Reymont's esoteric interests, the novel is very important: it presents a picture of the spiritual, esoteric and occult tendencies of the time, but most importantly, Reymont's personal experience:

In 1903-04 I published the first version of Chłopi; at first it was only one volume. I burned it and rewrote it. This time it was divided into four volumes (1904-09). Next, I wrote Wampir (1911) [The Vampire] - the reflection of my spiritualist exercises - two volumes of novellas, and I began historical studies concerning the decline of Poland toward the end of the seventeenth century (Reymont 1924).

The novel which is now known as The Vampire was initially to be titled In the Mists, referring to the its setting in London and to an aura of 
mysteriousness. It tells the story of a talented young writer Zenon. Zenon is a Polish émigré, who has had a complicated personal situation in Poland before coming to London, where he started a new life and got engaged to the beautiful Betsy. Through connections of a friend of his, Zenon learns about Spiritualism, Theosophy, Eastern teachings, and the hidden, spiritual side of life in general. He meets and becomes involved with a mysterious woman, Daisy, who came from India with a man called Mahatma Guru, and a panther called Bagh ${ }^{9}$. His personal situation is complicated by his ex-partner Ada, who comes to London with their daughter Wandzia. Many strange things start to happen to Zenon; he changes, falls into lethargy, and finally finds himself in a gothic ruin, observing mysterious rituals. Their central part is the appearance of Baphomet himself (in the company of Daisy), which is prefaced by a procession of Seth's entourage, alluding to Egyptian mysteries. The book concludes with Zenon's final choice concerning the path he would take in life.

\section{Ambiguity of the figure of the Vampire}

Interestingly, the word "vampire" itself never appears in the first part of the book; one would also be disappointed looing for figures with long claws, sipping blood. Although by the end of the novel "vampire" is used to refer to one of the characters - Daisy, the meaning of the title, if the book is taken as a whole, is unclear. Reymont toys with different possible meanings, some of which can only be recognized by readers familiar with his Eastern and Esoteric ideas. Seen from such a perspective, much of what Reymont describes is related to the image of a vampire in various traditions. Who or what is the Vampire in Reymont's novel then, and what has been missed or overlooked in the traditional reception of The Vampire? Let identifiy a multiplicity of meanings that refer to the Esoteric imagination. The meanings were not always directly indicated by the author, but they can be deduced from the novel.

The first meaning that can be distinguished is that of the vampire as a person who could be termed an energy vampire - a person who takes away others' power, and binds their thoughts. Their influence is manifested in feelings of weakness, sleepiness and loss of concentration. The second meaning is related to a figure with a maleficent spell or the power of evil sight - Reymont associates this meaning with the previous one. Daisy is called an energy vampire - she is a demonic woman (a redhead, of course), who seems to have the power of casting spells on people. She supposedly caused an unrecognized illness in a child. Here Reymont alludes to the trope of "evil sight", present in the folklore of many cultures. Anyone familiar with the common appearance of the phantom in Polish (Zmora) and South-Slavic (Mora) folklore, will have no problem grasp-

9 Bagheera was a name of the panther in R. Kipling's Jungle Book (1894); Reymont was an admirer of Kipling. 
ing the next meaning, which is a Vampire - Zmora (Phantom). This is one popular way of describing the sensation caused by sleep paralysis, a common sleep disorder, which is considered taboo in many cultures. This phenomenon is connected to the physiology of sleep: when a person is asleep, their body normally remains in a state of paralysis, so that they do not react to dream images in the REM phase. Sometimes one can wake up and become aware before the paralysis cedes, which results in an unpleasant experience of having no control over one's body and being unable to move or speak. It sometimes leads to hyperventilation, and results in a feeling of pressure on one's chest, as well as to hallucinations. Zmora, popular in Polish folklore, often seen as a kind of vampire, is a classic example of a hallucination in this context. In various folklores it could be connected to witches, demons like succubi or incubi, and vampires nonetheless characterizing similar physical sensations, and sharing similar features. A child in Reymont's novel describes such an experience as a visit of a kind of phantom. The phantom would come at night and sit on the bed, and the child would be unable move or make a sound. ("[...] she comes and sits right here, where Uncle is now sitting, and looks at me so scarily [...] I am so afraid and some such thing happens to me, that I cannot even tell Uncle... Neither can I move then, nor am I able to call out, or anything..."). The sensation is believed to be caused by a familiar, evil person (often a neighbor), which is a common understanding in Polish folklore of how Zmora works (Podgórscy 2005, Hess 2014).

The fourth meaning we will call the bounds of obligation - family as vampire. In the book the family (of one of the characters, Joe) is also a vampire, as it acts as one, and is itself a limitation (and so is the human existence as such). Joe says: "I have no family! I have rid myself of this vampire already! I have torn off all fetters. Nothing connects me to life anymore! I am leaving Europe forever! I am free, I have no need of country or family, or friends. I will wash my body in the holy waters of Ganges, and I will drown my soul in contemplation! The vile wailing of the human herd will not reach me there! I have suffered so greatly here! I have overcome the wretched instinct of life and I will overcome life itself!" (Reymont 1986: 291-292). The fifth meaning, mentioned previously, is the vampire as a femme fatale.

The sixth meaning does not appear as a term in the book, but is clearly discussed therein; it is a Vampire as the specter of Kama-Rupa. One of the most interesting meanings associated with the vampire in Reymont's novel, it is connected to the Theosophical vision of the world. In Theosophy of the Theosophical Society, the notion of a vampire appears in a precisely defined context, related to the conception of the body and spiritualist séances. Reymont's novel opens with a description of a séance, during which the specter of a certain person appears. As we can infer from the later parts of the book, the same person was in a different place at the same time, which is evidence of bilocation, or "de-stratification" of 
bodies. Briefly and oversimplifying, we can say that in the Theosophical conception, the human body is composed of seven elements, which are grouped into lower and higher principles. One of the lower principles, which is an image, a reflection of the physical body, is called kamarupa. It can become separated from the other bodies - in particular, such separation is part of the after-death process, which leads the higher principles to be reincarnated. One of the most important points on which spiritualists were criticized by Theosophists, who did not recognize the interpretation of séances proposed by the students of Kardec, was the claim that entities manifesting themselves during séances are the souls of the deceased. According to Theosophists, the soul could not usually be the source of the manifestation - rather it was the "phantom of kamarupa". Kamarupa, brought back down to Earth, instead of dissolving, became a vampire, which fed on the living energy it found on Earth. According to some Theosophical writings, however, such separation of bodies was also possible before death. In this context the kamarupa is called a "vampire" in Theosophical literature.

An important motif of The Vampire is the competition of two worldviews, and thereby of differing roads of spiritual practice - a Theosophical pantheism and radical dualism, which in Reymont's vision are constantly in conflict, and which cause strong emotions, pulling the protagonist apart.

As we can see, Reymont included in his novel many elements which are almost impossible to fully understand without knowledge of Theosophical teachings, Spiritualism and Spiritism, as well as hypnotism and research on mediumic phenomena of his time. Both The Vampire, as well as the previous shorter version titled In the Mists, would hugely benefit from a critical edition with a detailed commentary concerning their esoteric allusions and references. This would make it possible to gain a much better understanding of this important aspect of Reymont's work and life.

\section{Conclusion}

Having discussed the esoteric elements in Reymont's life and work, let us focus on to the question of why esoteric, but most importantly specifically Theosophical, interpretations of Reymont's legacy are rarely if ever found in Polish literary studies (which are, predictably, the main and most extensive secondary sources about the author). One may think that the answer is already entailed by an understanding of esotericism as rejected knowledge. As it is a current of thought that has been marginalized for decades, it could be expected that the majority of literary scholarship does not recognize its importance either. As we noticed at the beginning of this paper, for many reasons, ideas found by some to be 'unnecessarily strange' have disappeared from scholarly works, or at least they are treated as unimportant to the point that they are not worth discussing as a possible, let alone the main, framework for interpretation. That is, 
of course, one side of the problem. But it leads us to another one, which is the lack of acquaintance with esoteric ideas in general. If these ideas are not discussed themselves, it would be difficult to apply them as a tool for comparative analysis, and it is difficult to expect from literary scholars to be specialists in thea discipline of Western Esotericism which only emerged fully in the 1990s. All this also leads to the belief that esoteric inspirations could be embarrassing or even harmful to the image of a prominent author, and in order to preserve this image, they should not be highlighted.

Roots of these attitudes are to be found in a lack of awareness regarding the importance of the Western Esotericism to some authors in the context of their historical and cultural activity. It is not sufficient to know that, for example, Spiritualism was fashionable at the turn of the 20th centur; it has to be acknowledged that various currents of Western esotericism had a great impact on the main intellectuals of the time, and their metaphysical ideas were regularly discussed among intellectual and social elites at the time. Furthermore, it is essential to recognize the ideas themselves. Boiling down the topic of Esotericism to clichés like bouncing tables is not sufficient to make use of them in a thorough analysis.

It is possible to find bits and pieces of information about Reymont's engagement in certain spiritual practices, but there is a lack of general understanding concerning what metaphysical ground they had, and how they could have shaped his works, besides certain obvious motifs like séances as a plot theme. In my opinion it is of utmost importance to investigate if the author's interests were just an episode, as some suggest, or something closer to a life-long interest. Finding enough evidence to speak about the latter lends legitimacy to using this kind of interpretation, which at the present time still needs additional explanation and justification. That is why I believe that the first and very important step regarding the Western Esotericism framework in literary history (especially in Central and Eastern Europe where the topic is still neglected) is to introduce source-based studies, which can open discussions about the importance of esoteric influences and analyses of such examples; this would obviate the need to add extensive biographical introductions or other legitimization strategies in favor of a research framework of this kind every time. This is what I intended to offer here.

Let us now get back to our question. When we look closer at the relationship between Reymont's esoteric interests on the one hand, and research on Western Esotericism published in Poland on the other, we encounter two main problems: a confusion concerning the distinction between Spiritualism and Spiritism, and very little interest in and knowledge of the Theosophical Society and its beliefs among Polish scholars. Digging into them will lead to answers about the marginalization of Esotericism in interpretations of Reymont's works, or the misunderstanding of their essential meaning. 
In Polish there is unfortunately only one word in common use (and in some areas of scholarship) that corresponds both to Spiritualism and Spiritism, and this is spirytyzm, which is a literal translation of the latter term. This is an issue of great importance for intellectual history, as $19^{\text {th }}$ century Spiritualism and Spiritism are distinct phenomena. As a very short introduction we can say that Spiritualism (in the religious sense, not to be mistaken with the philosophical one) dates back to the ideas of Emanuel Swedenborg (1688-1772), and its $19^{\text {th }}$-century form emerged in New York State, following the Fox sisters' claims about contacts with spirits via "rapping" (1848). Spiritualism includes metaphysical beliefs about life after death, and the possibility of contacting deceased via a Medium, but it did not emerge as a new religious movement per se. Spiritism, on the other hand, is a system formed by the French Spiritualist Allan Kardec (pen name of Hippolyte Rivail, 1804-1869) as an explicit religious doctrine, which he named Spiritism precisely in order to differentiate it from the American tradition mentioned above. Thus, Spiritualism is a wider term, and while it developed to form church institutions, it is also a general worldview based on beliefs about afterlife rather than a strict doctrine, and it is shared widely by Christians and other denominations. Spiritism, conversely, was formed as a separate religion from its very beginning, its doctrines including, among others, reincarnation. In other words, Spiritism is a type of Spiritualism, sharing some of the basic ideas with the broader current, but also having important distinctive features.

While both Spiritualism and Spiritism involved the belief that during a séance an appearance of the soul (etheric body) of the deceased is possible, Theosophy objected to those interpretations, and proposed an explanation including many different Occult forces and beings as part of the séances. It also stressed that there were very limited possibilities of contact with an actual human soul of the deceased, condemning Spiritualistic explanations as theoretically and morally wrong. Theosophists proposed replacing Spiritualistic explanations with their Occult Philosophy.

Now, if in Polish studies the term Spiritism is the only one used, it is very hard to tell if a person called a Spiritist was involved in religious or just experimental activities. There is no way to tell if a particular group was involved in the American or French current, a mix of both, or perhaps in Occult philosophy, as the difference is rarely identified. In the case of Reymont, as we showed earlier, the differences between those groups were important, because at one point he started to speak about experiments rather than séances, and turned to the Occult philosophy, criticizing some Spiritists along the way.

The second problem that we highlighted here, is the lack of interest of Polish scholars in Theosophy of the The Theosophical Society in the recent decades. There are many reasons for this, but among them an important fact is that the Polish branch of the society was not officially reestablished after World War II. For several decades after the war, in Po- 
land, as in other countries of the Soviet bloc, studies of spiritual currents faced obstacles. Lack of extant data in open archives was also a problem. Another problem, of institutional character, was that there were very few institutes devoted to religious studies in Poland, and therefore studies on phenomena no longer existing in the country had to be less important than other research problems. The situation has changed a little after the so-called New Age outbreak, but the Theosophical current in Poland is still hugely understudied. For instance, there are publications identifying reincarnation as a distinctive Theosophical idea, but not recognizing it as a feature of Kardec's Spiritism, which leads to misinterpretations.

Regarding how the spiritual part of Reymont's life is absent from scholarly consideration, we can quote one of his biographers:

A significant, if rather funny, expression of the recognition that the writer began to receive came in the form of a ceremony in Grodno, where the venerable laureate Eliza Orzeszkowa ${ }^{10}$, during an evening at the club "Muse", which she herself founded, proclaimed the author of The Peasants her spiritual successor. The paradoxical nature of this ceremony consisted in the fact that it would be difficult to find any internal connections between the author of On the Niemen [Orzeszkowa - KMH], a steadfast proclaimer of the priestly ministry of literature, and Reymont, who never acknowledged such a vocation in any one of his works. The true successor of Orzeszkowa was Żeromski, and only him, but the priestess of Grodno despised the author of The Story of Sin as much as Reymont did (...). Their mutual antipathy for him was supposed to be one of the elements of a spiritual affinity (Krzyżanowski 1937: 9).

We see in this fragment how much Theosophy, or more broadly speaking, esoteric spirituality, was marginalized as a biographical element. From our perspective it seems obvious that Orzeszkowa, who was engaged in the Theosophical movement (Hass 1984: 88), anointed as her spiritual successor an author who shared her interests in this area, as well as her worldview. The author of the cited passage does not hesitate for a minute before reducing spirituality to the question of the purpose of literature, and then with unshaken certainty indicates a mutual dislike of another writer as the basis of this supposedly "spiritual" affinity. If the author had known that Orzeszkowa was a member of Kazimierz Stabrowski's Theosophical circle, which later transformed into the Warsaw Theosophical Society, and that Reymont considered her to be his teacher, and defined himself as an Occultist, perhaps he could have imagine that spirituality was something that went far beyond literature for these two writers.

Given these considerations, the first thing to be done when it comes to interpretations of Reymont's legacy had to be to identify the exact currents he followed, and their specific ideas. Here we presented some of the lost traces of his interests, filled the gaps in the biographical data, and

10 Eliza Orzeszkowa (1841-1910) was a renowned author, one of the most important Polish writers of her time, a proponent of Positivism (understood as a current in Polish literature). 
tried to shine a new light on the author's works. Seeing novels like The Vampire from the perspective of the author, instead of marginalizing them based on the negative views of literary critics, is a good start for the analysis of the often rejected elements, but it also tells us something about those elements. Reymont provides us with insight into the cultural discussions of his time, and by discussing two different worldviews of esoteric origin, and dwelling both on their exciting and frightening sides, allows us to learn more about how crucial and inspiring they used to be at the turn of the $20^{\text {th }}$ century.

\section{BIBLIOGRAPHY}

Besant A., An Exposition of Theosophy. Boston, Mass. 1893.

Bukowski K. Władysław St. Reymont. Próba charakterystyki. Lwów-Warszawa-Kraków: Wydawnictwo Zakładu Narodowego Imienia Ossolińskich 1927.

Choynowski P. Dusza Reymonta. „Tygodnik Ilustrowany” No. 2. 1926.

Dębicki Z. Wł. St. Reymont - Laureat Nobla. Warszawa - Kraków - Lublin - Łódź - Paryż - Poznań - Wilno - Zakopane: Gebethner i Wolff 1925.

Geron M. Grupa Pięciu. In Sztuka lat 1905-1923. Malarstwo - rzeźba - grafika - krytyka artystyczna. M Geron, J. Malinowski ed., Toruń: Wydawnictwo Interdyscyplinarnego Koła Naukowego Doktorantów Mikołaja Kopernika 2006.

Hanegraaff W. Esotericism and the Academy. Rejected Knowledge in Western Culture. Cambridge and New York: Cambridge University Press 2012.

Hanegraaff W. Occult/Occultism. Entry in: Dictionary of Gnosis and Western Esotericism, W. Hanegraff et. al, Brill: Leiden, Boston 2006.

Hass L. Ambicje rachuby, rzeczywistość. Wolnomularstwo w Europie Środkowo-Wschodniej 1905-1928, Warszawa: PWN 1984.

Hass L. W ujarzmionej stolicy: bez loży (1831-1905). “Ars Regia” 3/3-4 (8-9) 1994.

Hess K. M. The Idea of Ideoplasty and Occult Phenomena in the Theoretical and Empirical Research of Julian Ochorowicz. „Preternature: Critical and Historical Studies on the Preternatural” Vol. 7, No. 2, 2018.

Janion M. Wampir. Biografia symboliczna. Gdańsk: Słowo/Obraz Terytoria 2008.

Jocz A. Przypadek „osy rozbójniczej”. Rozważania o gnostycyzmie i neognozie w literaturze polskiej przełomu XIX $i$ XX wieku, Poznań: Wydawnictwo Naukowe Uniwersytetu im. Adama Mickiewicza 2009.

Kipling, Rudyard. Entry in Mackey's Encyclopedia of Freemasonry, online version at http://www.phoenixmasonry.org/mackeys_encyclopedia/k. htm [accessed 12.09.16].

Kocówna B. Reymont. Opowieść biograficzna. Warszawa: Ludowa Spółdzielnia Wydawnicza, 1971. 
Kocówna B. Władysław Reymont. Warszawa: Państwowe Wydawnictwo Naukowe 1986.

Kruszczyńska P., O Wampirze Władysława Stanisława Reymonta, "Annales Universitatis Mariae Curie-Skłodowska, Vol. 30 (2), 2012.

Krzyżanowski J. Władysław St. Reymont. Twórca i dzieło. Lwów: Wydawnictwo Zakładu Narodowego im. Ossolińskich 1937.

Malik J. A. Modernistyczne credo. O religijności Władysława Stanisława Reymonta. Tezy biograficzne. In Inny Reymont. W. Książek-Bryłowa ed. Lublin: Wydawnictwo Marii Curie Skłodowskiej 2002.

Manuscripts of W. Reymont in the Archives of Zakład Narodowy im. Ossolińskich in Wrocław, signature 6971/1, k. 39-42.

Markiewicz H. Władysław Stanisław Rejmont (właściwie Stanisław Władysław Rejment). Entry in Polski Słownik Biograficzny Vol. 31, 1988-1989.

Matuszewski I. Czarnoksięstwo and medyumizm. Studium historyczno-porównawcze. Warszawa: Gebethner i Wolff, 1896.

Nasi powieściopisarze o sobie - Władysław Reymont, „Świat” Vol. 14, No. 20.06.1913.

Ochorowicz J. De la suggestion mentale Paris: Doin, 1887.

Ochorowicz J. Zjawiska mediumiczne. Warszawa: Alfa 1992.

Podgórscy B. \& A. Wielka Księga Demonów Polskich - leksykon i antologia demonologii ludowej, Katowice: Wydawnictwo KOS, 2005

Przybyszewski S. Listy, Vol. 1-2. S. Helsztyński ed., Gdańsk: Towarzystwo Przyjaciół Nauki i Sztuki; Warszawa: Spółka Wydawnicza „Parnas Polski” 1937 - 1938, Vol. 3. Wrocław: Zakład im. Ossolińskich 1954.

Przybyszewski S. Synagoga szatana. Przyczynek do psychologii czarownicy [in] S. Przybyszewski, Confiteor. Synagoga szatana. Warszawa: Spółdzielnia Wydawnicza Anagram 1999/2000.

Reymont W. Biographical. 1924. The Nobel Prize in Literature 1924, https:// www.nobelprize.org/prizes/literature/1924/reymont/auto-biography/ [accessed 09.09.2016].

Reymont W. Chłopi: powiesśc współczesna. Warszawa: Gebethner i Wolff, Kraków: G. Gebethner i Sp. 1904-1909.

Reymont W. Komedyantka. Warszawa: Gebethner i Wolff 1896.

Reymont W. Lato 1894 za granica. Wrocław: Wydał z autografu Tadeusz Mikulski 1948.

Reymont W. Listy do rodziny. T. Jodełka-Burzecki, B. Kocówna ed. Warszawa: Państwowy Instytut Wydawniczy 1975.

Reymont W. Listy Władysława Stanisława Reymonta do brata, ed. by B. Kocówna and Z. Jakimowicz, "Pamiętnik Literacki: czasopismo kwartalne poświęcone historii i krytyce literatury polskiej” 60, issue 2, 1969.

Reymont W. Marzyciel. (I wyd. 1908) Marzyciel, Franek, Lili. Warszawa: Ludowa Spółdzielnia Wydawnicza, 2000.

Reymont W. Nowele. Adam Bar ed. Warszawa: Gebethner i Wolff 1951.

Reymont W. W palarni opjum in Reymont, Ave patria, Z. Dębicki ed. Warszawa: Wydawnictwo Tygodnika Ilustrowanego 1932. 
Reymont W. Wampir, Książka i Wiedza 1986.

Reymont W. Wampir: powieść. Warszawa: Gebethner i Wolff, Kraków: G. Gebethner i Sp. 1911a.

Reymont W. Z ziemi chetmskiej: wrażenia i notatki. Warszawa: Gebethner i Wolff, Kraków: G. Gebethner 1911b.

Reymont W. Ziemia obiecana. Vol. 1-2, Warszawa: Gebethner i Wolff, Kraków: G. Gebethner i Spółka 1899.

Sell A. Lęki i fascynacje społeczeństwa fin de siècle’u w Wampirze Władysława Stanisława Reymonta. In Groza w kulturze polskiej, R. Dudziński, K. Kowalczyk, J. Płoszaj ed. Wrocław 2016.

Sołtysik M. Aura wokół Reymonta. „Palestra” 11-12, 2005.

The Theosophical Society in England, Membership Register Index 1893.

Tokarz W. W rosyjskiej szkole. „Iskry” 9-10, 1925.

Trześniowki D., Wampir Reymonta: upiorne sny zmęczonej Europy. In Inny Reymont, W. Książek-Bryłowa ed. Lublin: Wydawnictwo Marii Curie Skłodowskiej 2002.

Walczak M. Władysław Reymont o snach i spirytyzmie. In Inny Reymont. W. Książek-Bryłowa ed. Lublin: Wydawnictwo Marii Curie Skłodowskiej 2002.

Wladyslaw Stanislaw Reymont Facts, The Nobel Prize, The Nobel Prize in Literature 1924, https://www.nobelprize.org/prizes/literature/1924/reymont/facts/ [accessed 10.10.2016].

Zagadnienia Metapsychiczne No. 2-7 (Vol.1-2), 1924-1925.

Каролина Марија Хес

Фасиинаиија Влаяислава Рејмонйа окулииним: Биоірафске и умейничке везе

Резиме

Станислав Владислав Рејмонт је рођен као Станислав Владислав Рејмент 1867. године у селу Кобјеле Вјелкје као један од деветоро деце; отац му је био музичар, а мајка је потицала из осиромашеног нижег племства. Као младић, често је мењао пребивалиште и занимање. Био је обућар, радио је у позоришту, и најзад почео да пише приповетке и романе. Важна дела писао је почев од 1890-их. Године 1900. након озбиљне несреће у возу, која је довела до трајних здравствених проблема, добио је издашну накнаду, што му је омогућило да се посвети писању током потоњих година. Оженио се Аурелијом Шабловском 1902. године. Добио је Нобелову награду за књижевност 1924. за епски роман Сељаци. Преминуо је наредне године у Варшави.

Рејмонта су занимали спиритуализам, теозофија, источњачка мисао и мистицизам. Почео је да учествује у сеансама највероватније 1890. године, на наговор свог бившег професора и групе истакнутих спиритуалиста. Требало 
је да буде „одабрани спиритуализма”, и почео да путује са групом верника који су му обезбедили средства за живот и образовање. Могуће је да је имао улогу медијума. Званично, тај период није дуго трајао и Рејмонт је напустио тај кружок, оптужујући их да варају и да су наивни. Међутим, из других извора се може сазнати да је тада већ ступио у контакт са другим окултистима. Како видимо из његових сопствених изјава, касније је сматрао себе окултистом, за разлику од спиритуалисте. Био је члан, и вероватно један од оснивача, удружења видовњака по имену Варшавско психолошко удружење, које није имало дозволу власти. Задржао је ово интересовање до краја живота, будући да је 1924, исте године када је добио Нобелову награду, постао члан одбора

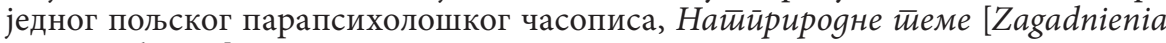
Metapsychiczne], и остао на тој позицији до смрти.

Рејмонт се дружио са неким од првих теозофиста у Пољској - Владиславом Валдеровичем и др Јозефом Джевјецким. Заједно са потоњим, Рејмонт је учествовао на Теозофском конгресу, одржаном у Ложи Блавацки у Лондону, од 13. до 15. јула 1894. Тамо је лично упознао Ени Бесант, као и друге истакнуте теозофисте (писао је о Хенрију Олкоту и Џ.Р.С. Миду). Ова искуства је описао у аутобиографском есеју „Лето 1894. у иностранству” (1948). Поред ових инспирација, Рејмонт се након свог путовања у Лондон спријатељио са др Јулијаном Охоровичем (1850-1917), који се бавио истраживањем хипнотизма и феномена који се тичу медијума. Провео је доста времена у својој кући у Висли, где започиње рад на Сељацима, а у међувремену присуствује Охоровичевим експериментима са медијумом. Касније је своје опсервације укључио у роман Вамӣup, у коме се појављују спиритуалисти и теозофисти, као и мноштво тема у вези са окултним струјањима, попут оних које је инспирисало пријатељство са харизматичним и контроверзним писцем Станиславом Пшибишевским (1868-1927). У раду се фокусирамо на езотеричне мотиве у роману и на крају анализирамо зашто се езотеријска, а нарочито конкретно теозофска, тумачења Рејмонтовог наслеђа ретко или никад не могу наћи у књижевним студијама.

Клучне речи: Владислав Рејмонт, западна езотерија и књижевност, теозофија, спиритуализам, спиритизам, западна езотерија у Пољској, Теозофско друштво, Вампир, Јозеф Джевјецки

Примљено: 20. 12. 2018.

Прихваћено: 20. 12. 2019. 